\title{
Application of ultrafiltration and electrodialysis techniques in lactic acid removal from whey solutions
}

Renata Oberherr, Renata Fioravante Tassinary, Letícia Vognach, Simone Stülp+(i)

University of Vale do Taquari (Univates), Center of Sciences and Engineering, 171 Avelino Tallini, Lajeado, Rio Grande do Sul, Brazil.

+Corresponding author: Simone Stulp, Phone: +55 51 3714-7025, email address: stulp@univates.br

\section{ARTICLE INFO}

Article history:

Received: March 19, 2019

Accepted: July 25, 2019

Published: November 20, 2019

\section{Keywords:}

1. lactic acid

2. electrodialysis

3. ultrafiltration

4. whey

ABSTRACT: Due to the biotechnological value of whey, this work aims at applying the ultrafiltration (UF) and subsequently the electrodialysis (ED) techniques in pilot scale plant. Whey (5\% concentration) was treated twice by the UF technique, with a pressure of 4 bar (flow mode $\left.20 \mathrm{~L} \mathrm{~h}^{-1}\right)$. The permeate obtained was submitted to the ED process, in which $12 \mathrm{~V}$ were applied for $4 \mathrm{~h}$. In order to evaluate the UF, parameters as turbidity, color, TOC and $\mathrm{pH}$ were measured. Regarding the $\mathrm{ED}$ technique, parameters as $\mathrm{pH}$, conductivity, calcium, sodium and lactic acid concentration were evaluated. The electrodialysis unit was operated

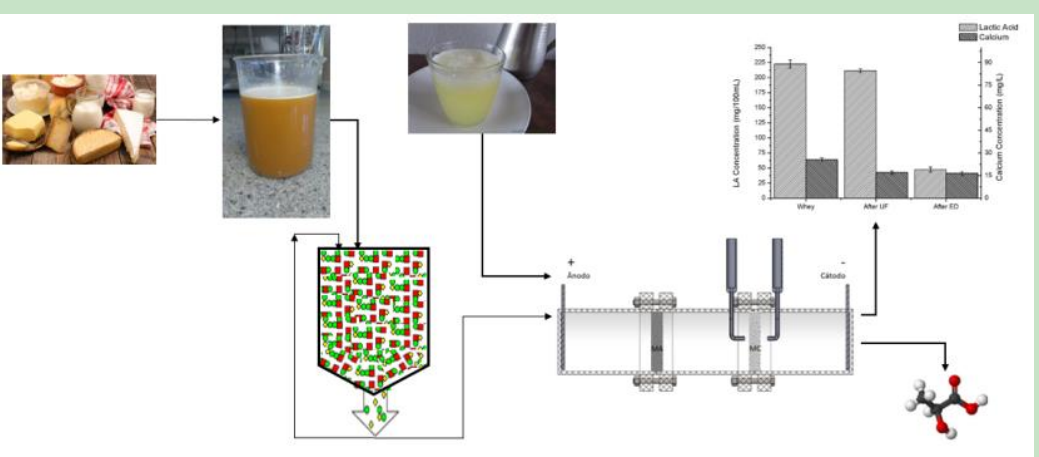
on a constant voltage, and tested the range was from 3 to $12 \mathrm{~V}$. After the UF and ED processes, the $\mathrm{pH}$ remained unchanged. Thereafter the UF treatment, the initial turbidity was reduced by $99.9 \%$. In terms of parameter reduction after ED, the calcium concentration was decreased in $36.0 \%$ soon after UF and ED treatments, and the lactic acid concentration in $80.0 \%$. These results point to the possible combination of UF and ED to treat the whey and signals the potential of further using the resulting solutions as inputs in new applications in the food industry such as lactose.

\section{Introduction}

Whey is one of the by-products of high added value in the dairy industry, by the expressive volume generated as well as by its composition, containing important nutrients. In this process ${ }^{1}$, there is no total feedstock conversion in final product, hence, for each kilogram of cheese produced, an average of 10 liters of whey is generated. The milk whey consists, basically, of 94 to $95 \%$ water, 3.8 to $4.9 \%$ lactose, 0.8 to $1.0 \%$ protein and 0.7 to $0.8 \%$ of minerals ${ }^{2}$. In terms of Chemical Oxygen Demand (COD), the content of organic compounds is around $60,000 \mathrm{mg} \mathrm{L}^{-1} 3$.

According to some authors ${ }^{4-6}$, there are numerous current alternatives for the use of fresh milk whey and its components. Among the alternatives, it can be mentioned, for example, animal feed, production of ricotta, dairy drink, whey powder production, which can be also used in the pharmaceutical industry.

One of the main stages to produce biotechnological products is drying out the whey using a spray dryer equipment. The presence of lactic acid in whey (containing lactate ions) promotes products that are more susceptible to moisture absorption ${ }^{7}$, because of the hygroscopic behavior. This phenomenon allows the formation of powdered agglomerates that cannot be tolerated in this process.

The membrane separation processes (MSP) go through clean technology which play an important role in the separation of whey components ${ }^{8}$, such as proteins and lactose with subsequent drying. 
Such components both contribute to the environment improvement and provide gains to industries. In addition, they are more valued when segregated.

Ultrafiltration (UF) is an alternative and attractive method, since it does not use heat as well as a phase change. This technique is usually applied to retain macromolecules and has been widely used in the dairy industry for the recovery of important components and compounds ${ }^{9,10}$. The UF allows the concentration variance among different compounds, due to the protein retention and selective permeation of lactose, minerals, water and compounds of low molar mass.

Electrodialysis (ED) is an electrochemical technique and shows benefits when compared to traditional processes, since it does not require phase change or addition of chemical reagent, as well as its operational cycle is continuous. It has been widely used in water and wastewater treatment for the removal of ions, for example, ionic species in solution are transported in compartments of a cell through ion-selective, anionic and cationic membranes by the action of an electric field. In addition to this, electrodialysis is an alternative $\mathrm{e}^{11,12}$, method of lactose separation and concentration, when whey solutions are used.

In this context, the aim of this study is to investigate the potential applicability of combining ultrafiltration and ED techniques (in a pilot scale system), in order to remove lactic acid (LA) and other ions from whey, focusing on biotechnological applications.

\section{Materials and methods}

The research consisted in the recovery of whey (5\% concentration) and the purification treatment was carried out twice by the UF technique, in a pilot scale plant (flow mode $20 \mathrm{~L} \mathrm{~h}^{-1}$ ), and the permeate obtained was submitted to the ED process in a prototype pilot scale (Fig. 1).

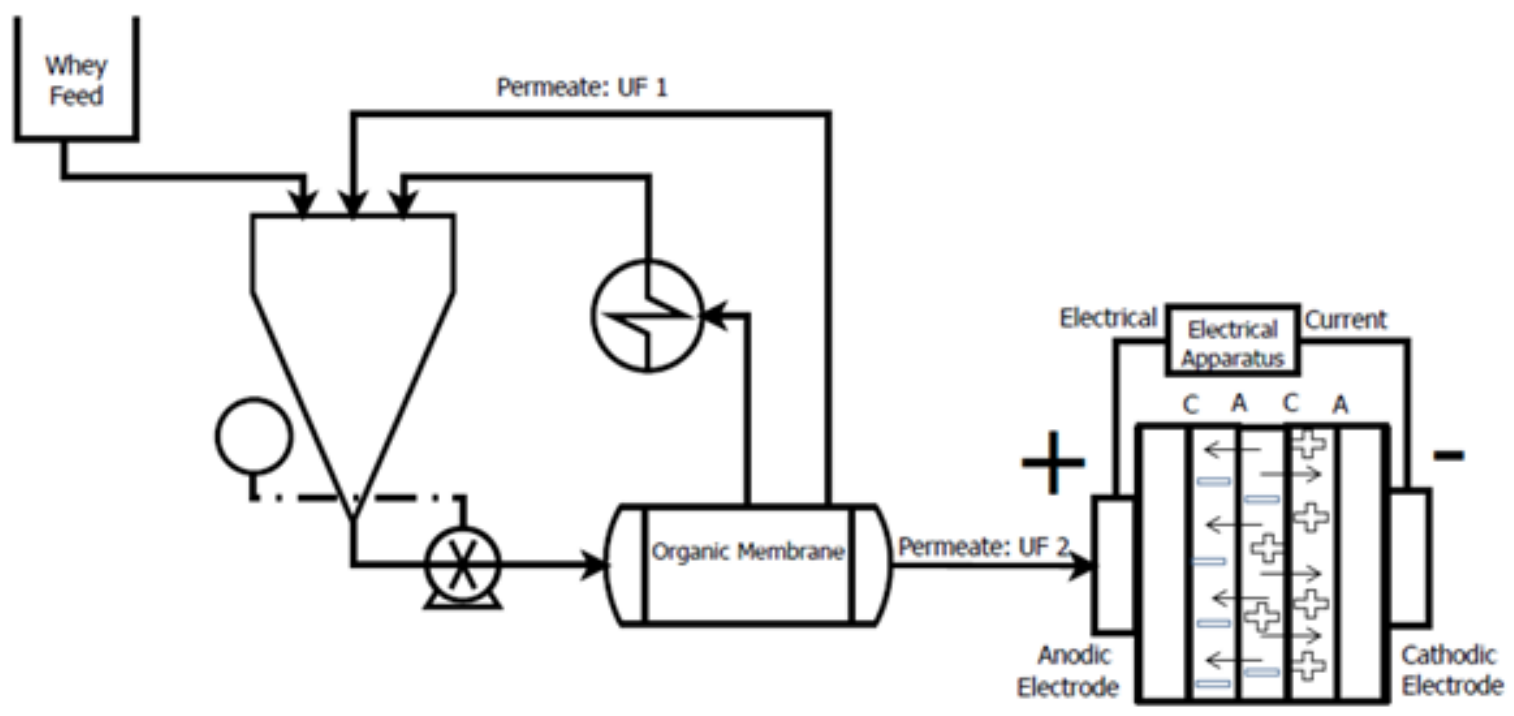

Figure 1. Schematic diagram of ultrafiltration and electrodialysis treatments.

In the ultrafiltration experiments, the volume of permeate was evaluated, and it was collected to determine the flux. In addition, the whey was ultrafiltered under varied conditions, i.e., $\mathrm{pH}$ ranging from 5.9 to 7.0 and transmembrane pressure (TMP) ranging between 3.5 and 5.0 bar. After this evaluation, the TMP was maintained at 4 bar and pH 5.9. The UF membrane was AG1812, made of polyethersulfone, manufactured by GE Water. The molar weight cut-off was $200 \mathrm{kDa}$, and permeation area was $0.37 \mathrm{~m}^{2}$. The UF experiments were conducted in batch processing. In this process, the concentrate stream return to the begin, like total recirculation mode. The whey was ultrafiltered two times.

After UF treatments, the permeate obtained was submitted to the ED process, in which $12 \mathrm{~V}$ were applied for $1 \mathrm{~h}$ (for evaluation) and $4 \mathrm{~h}$ (total treatment time), in an acrylic cell containing five compartments (total volume of $7 \mathrm{~L}$ ). In this system, the cathode was a titanium plate and the anode, a $70 \mathrm{TiO}_{2} / 30 \mathrm{RuO}_{2}$ plate $\left(189 \mathrm{~cm}^{2}\right)$. The 
electrodialysis cell was operated on a constant electrochemical potential, and the potential range was 3 to $12 \mathrm{~V}$. The area per ion exchange membrane (AMV and CMV Selemion) was $63.61 \mathrm{~cm}^{2}$.

\subsection{Analysis of limiting current in ED process}

Initially, the limiting current in ED process has been determined using a $\mathrm{CaCl}_{2}$ solution for comparison with the results of $\mathrm{Na}^{+}$ions, according to the Tanaka ${ }^{14}$, in a cation-exchange membrane, to simulate $\mathrm{Ca}^{2+}$ ions present in whey. In this evaluation, a constant current source ICEL PS7000 was used to apply successive increments of electrical current each two-minute intervals, in a cell containing $0.1 \mathrm{~mol} \mathrm{~L}^{-1} \mathrm{CaCl}_{2}$ solution. The cationic membrane potentials were measured (multimeter MINIPA ET-2081) using a multimeter connected to two reference electrodes ( $\mathrm{Ag} / \mathrm{AgCl} / \mathrm{KClsat})$ with Luggin capillary placed at the membrane's interfaces (in a three-compartment acrylic cell). In this experiment, the cathode was a titanium plate and the anode a $70 \mathrm{TiO}_{2} / 30 \mathrm{RuO}_{2}$ plate $\left(8.9 \mathrm{~cm}^{2}\right)$. At the end of each interval data of applied current, potential of the system and membrane were recorded.

\subsection{Sample analysis}

The parameters evaluated for the UF treatments were: turbidity (Digimed DM TU), Total Organic Carbon - TOC (Shimadzu TOC-V $\mathrm{V}_{\mathrm{CPH}}$ ), Total Nitrogen (Shimadzu TNM-1), Color (Co-Pt), conductivity (856 Metrohm Module) and $\mathrm{pH}$
(827 pH Lab Metrohm). For the ED technique, the parameters evaluated were $\mathrm{pH}$ and conductivity. A HPLC Shimadzu, LC-20AT, detector DAD: SPD M20A, Autosampler: SIL-20A HT with Supelcogel C-610H; $0.8 \mathrm{~mL} \mathrm{~min}^{-1} \mathrm{H}_{2} \mathrm{SO}_{4} 0.05 \mathrm{~mol}$ $\mathrm{L}^{-1}$, temperature $=50{ }^{\circ} \mathrm{C}, \lambda=207 \mathrm{~nm}$, retention time $=9.90 \mathrm{~min}$, was used to detect lactate ions ${ }^{6}$. Calcium ions were detected by an Atomic Absorption Spectrometer (Perkin Elmer PinAAcle 900T), $\lambda=422.67 \mathrm{~nm}$.

\section{Results and discussion}

\subsection{Evaluation of ultrafiltration and ED treatments}

To evaluate the efficiency of UF and ED techniques, some initial parameters were analyzed.

\subsubsection{Evaluation of ultrafiltration conditions}

The results of water and whey flux vs. transmembrane pressure are shown in Fig. 2. It is possible to observe that the water flow increased linearly in function of the TMP $\left(r^{2}=0.9229\right)$, and for whey solutions the behavior was linear with different slope. The same behavior was found in another study ${ }^{13}$.

The transmembrane pressure during Ultrafiltration process was optimal at 4.0 bar. Lower pressure resulted in a decreased flow, in function of lower driving ${ }^{15}$. Also, previous studies showed that higher values of pressure promote an irreversible fouling ${ }^{16}$. 


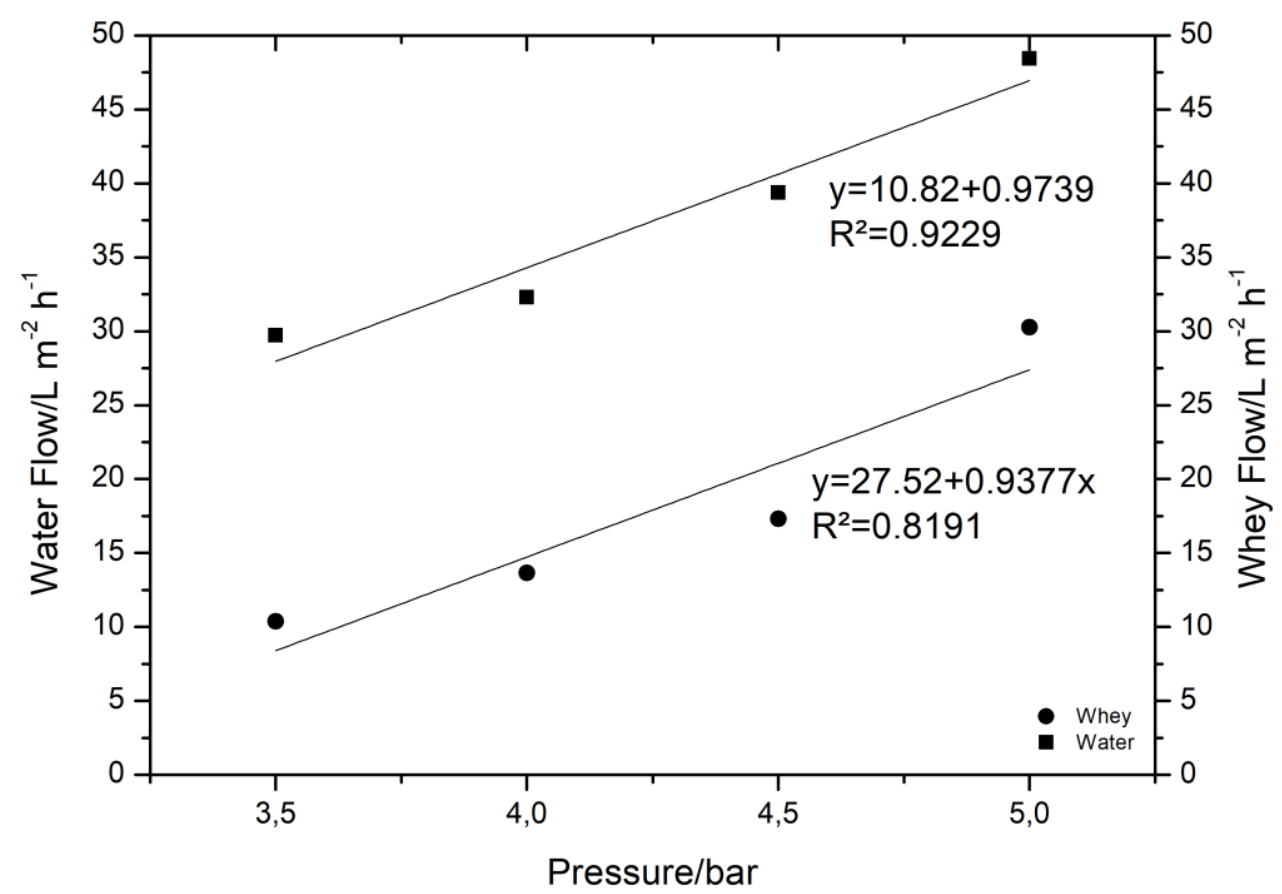

Figure 2. Water and whey flux $v s$ transmembrane pressure. Membrane AG1812, $\mathrm{T}=25^{\circ} \mathrm{C}$, feed flow rate $=20 \mathrm{~L} \mathrm{~h}$. Legend: (घ) water, $(\bullet)$ whey.

The evaluation of the ultrafiltration technique was performed by monitoring the turbidity and reduction of color (Co-Pt). In Table 1 , results of whey flux $\left(\mathrm{L} \mathrm{m}^{-2} \mathrm{~h}^{-1}\right)$, reduction of turbidity and color are shown, and in this ultrafiltration system, the best results were obtained using pressure at 4 bar and $\mathrm{pH}$ 5.9.

Table 1. Results of experimental conditions and turbidity and color removed after ultrafiltration process

\begin{tabular}{|c|c|c|c|}
\hline Conditions (pressure and $\mathrm{pH}$ ) & $\begin{array}{c}\text { Whey } \\
\text { flux/L } \mathbf{~ m}^{-2} \mathbf{h}^{-1}\end{array}$ & $\begin{array}{l}\text { Reduction of } \\
\text { turbidity/\% }\end{array}$ & Reduction of color $/ \%$ \\
\hline 4.0 bar - pH 5.9 & 15.69 & 94.81 & 73.81 \\
\hline 4.0 bar $-\mathrm{pH} 7.0$ & 16.60 & 92.72 & 70.54 \\
\hline $4 ; 5$ bar - pH 5.9 & 18.83 & 99.23 & 67.33 \\
\hline
\end{tabular}

The $\mathrm{pH}$ is an important parameter to show the behavior of whey in the ultrafiltration plant. It is a precautionary measure with respect to the range of $\mathrm{pH}$ allowed to the membrane. The turbidity and measure of color are quality indicators of solution. The first one is linked to the concentration in colloidal substance in suspension present in the sample and the second one, as well as turbidity also is the result of the light scattering, relatively. The increase of the pressure, hence increase the removal rate of turbidity and decrease the removal rate of color.
These turbidity results are in line with other studies $^{17,18}$, when evaluate the ultrafiltration performance for the same endpoint, also find high removal rate. Though, the same dos not occur to the measure of color. This parameter is related to the quality of the treatment, according to another study $^{13}$, higher pressure decreases the quality of the permeate. 


\subsubsection{Evaluation of electrodialysis conditions}

A typical current-potential of the membrane $\left(\mathrm{U}_{\mathrm{m}}\right)$ curve observed in working ED unit is depicted in Fig. 3, for the electrodialysis of a $0.1 \mathrm{~mol} \mathrm{~L}^{-1}$ $\mathrm{CaCl}_{2}$ solution. For the cationic membranes evaluation, the second region (plateau) in the graphic of Fig. 3 determines a limiting current between 1.79 and $2.02 \mathrm{~mA} \mathrm{~cm}^{-2}$ with cell potential $\left(E_{\text {cell }}\right)$ around $13 \mathrm{~V}$. After this evaluation, the limiting current was also determined using the work solution (whey), and the results were comparable.

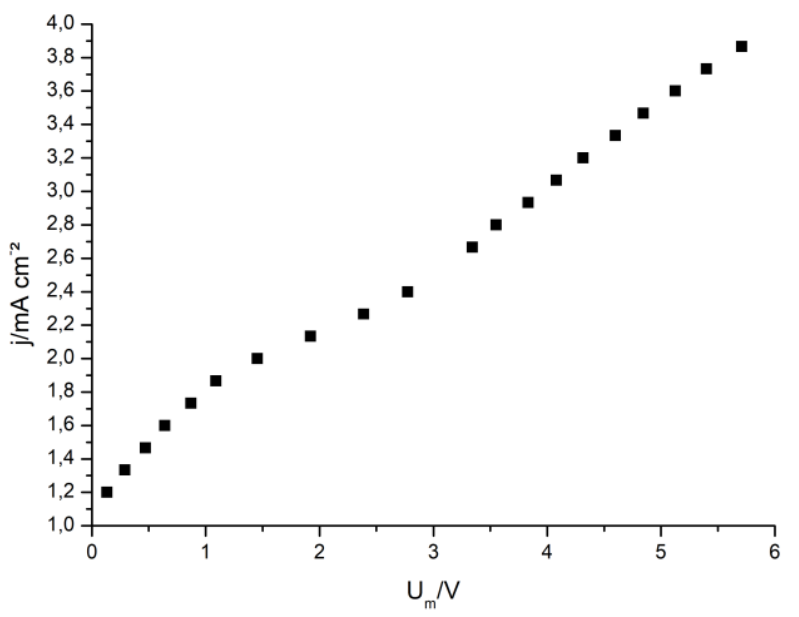

Figure 3. Current-potential of the membrane $\left(U_{m}\right)$ curve observed in working ED unit, for the electrodialysis of a $0.1 \mathrm{~mol} \mathrm{~L}^{-1} \mathrm{CaCl}_{2}$ solution.

In terms of the removal rate of the of $\mathrm{Ca}^{2+}$ and $\mathrm{Na}^{+}$cations, applying ED treatment for $1 \mathrm{~h}$ (for evaluation this treatment), the results are in Table 2, and, in this evaluation, the best results were obtained using a voltage of $12 \mathrm{~V}$. Also, after the ED treatment (operated with a constant $12 \mathrm{~V}$ ), the initial concentration of lactate ions was reduced in $36.31 \%$. The conductivity of the whey solution (after UF) was around $17.4 \mathrm{mS} \mathrm{cm}^{-1}$.
Table 2. Percentage of ions removed from whey solutions after $60 \mathrm{~min}$ of a batch electrodialysis process.

\begin{tabular}{|c|c|c|}
\hline $\begin{array}{c}\text { Cell } \\
\text { voltage/ } \mathbf{V}\end{array}$ & $\begin{array}{c}\text { Removal of } \\
\mathbf{N a}^{+} \text {ions } / \%\end{array}$ & $\begin{array}{c}\text { Removal of } \\
\mathbf{C a}^{2+} \text { ions } / \%\end{array}$ \\
\hline $\mathbf{3}$ & 5.91 & 4.34 \\
\hline $\mathbf{6}$ & 2.16 & 9.68 \\
\hline $\mathbf{1 2}$ & 13.00 & 14.63 \\
\hline
\end{tabular}

\subsection{Purification and demineralization of whey by} $U F$ combined with $E D$

After the initial evaluation of some parameters in the UF and ED techniques, the purification and demineralization of whey by UF combined with ED were investigated. Fig. 4 shows that the initial flow decays to approximately constant values, from $15.63 \mathrm{~L} \mathrm{~m}^{-2} \mathrm{~h}^{-1}$ (initially), to $9.5 \mathrm{~L} \mathrm{~m}^{-2} \mathrm{~h}^{-1}$ (after $80 \mathrm{~min}$ ), similar results were shown in previous study $^{19,20}$.

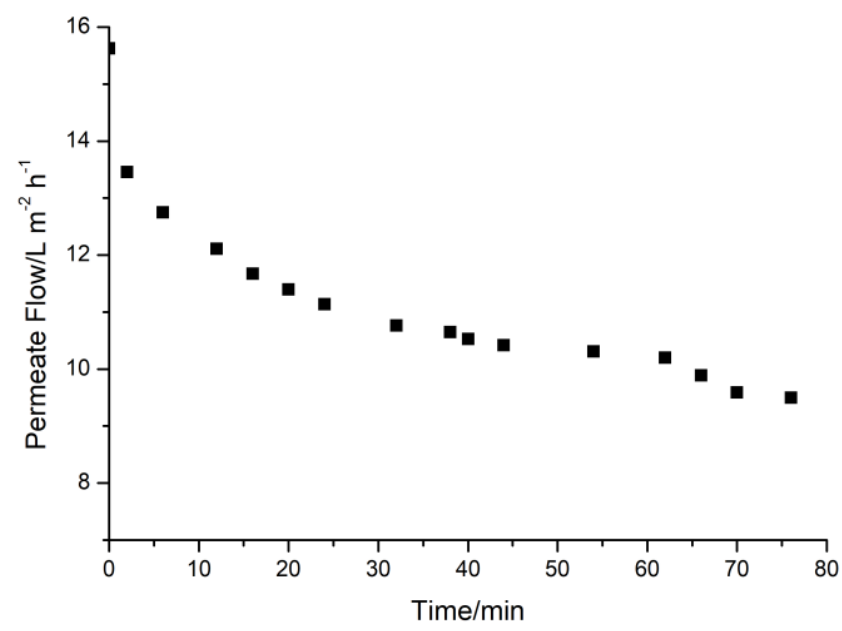

Figure 4. Average flux as a function of time for whey solutions at 4 bar.

The phenomenon of permeation flux reduction must be evaluated to avoid compromising the application of ultrafiltration technique in real systems (scale up). In this study, the whey solution has a $\mathrm{pH}$ of 6.2 , soluble total organic carbon (TOC) of $8.1 \mathrm{~g} \mathrm{~L}^{-1}$ and total nitrogen of $3.5 \mathrm{~g} \mathrm{~L}^{-1}$.

The results of concentration in terms of anions (lactate ions) and cations $\left(\mathrm{Ca}^{2+}\right)$, after ultrafiltration (twice) and electrodialysis treatment $(4 \mathrm{~h}-$ total time), are shown in Fig. 5. After the electrodialysis process, the conductivity of the treated solution was around $15.69 \mathrm{mS} \mathrm{cm}^{-1}$ this result demonstrates the demineralization after $\mathrm{ED}^{6}$. 


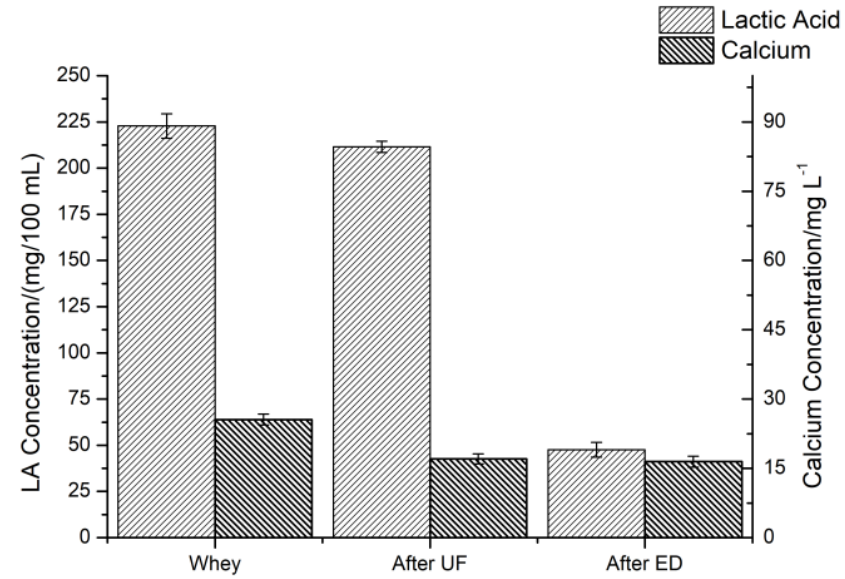

Figure 5. Lactic acid and ion calcium concentration before and after ultrafiltration and ED $(4 \mathrm{~h})$.

After the UF and ED processes, the $\mathrm{pH}$ remained unchanged, and the initial turbidity was reduced by $99.93 \%$. The calcium concentration was decreased in $36 \%$ in the permeate solution, the lactic acid concentration in $80 \%$ (after UF + ED), and the TOC was reduced in $56 \%$.

The removal of lactate ions occurs at a slower rate compared to other ions present in whey (when applied ED technique during 1 and $4 \mathrm{~h}$ ), due to the more complex nature ${ }^{8,19}$. Furthermore, the final calcium concentration (after $4 \mathrm{~h}$ ) was $41.13 \mathrm{mg} \mathrm{L}^{-1}$ and in terms of acid lactic, the final concentration was $43.65 \mathrm{mg} / 100 \mathrm{~mL}$; and the final acid lactic concentration was $43.65 \mathrm{mg} / 100 \mathrm{~mL}$; and the decrease of electrical conductivity of the permeate solution is function of time and indicates the efficiency of the ED treatment ${ }^{21}$.

These result points to the possible combination of UF and ED to treat the whey and signal the potential of further using the resulting solutions as inputs in new applications in the food industry, such as lactose. In addition, for the whey to be adequately treated by the spray dryer technique, a reduction of the lactic acid concentration is required, being an important step in the milk industry (specially to increase the shelf life).

\section{Conclusions}

The combination of both methods ultrafiltration (UF) and electrodialysis (ED) is useful to remove the lactic acid and calcium ions from whey, through UF (twice steps) to concentrate and purify lactate, before submitting the permeate in $\mathrm{ED}$ treatment $(4 \mathrm{~h})$. After the treatments, the initial turbidity was reduced by $99.93 \%$. The calcium concentration was decreased in $36 \%$ in the permeate solution, and the lactic acid concentration in $80 \%$ (after UF + ED). In UF was observed the membrane fouling phenomenon. This phenomenon occurred because have been colloidal material and macromolecules have been depositing at the membrane surface area promoting a low permeate flux. All these in UF system have been totally depended of $\mathrm{pH}$ and transmembrane pressure. In the first minutes of the pilot scale operation, the permeate flow decreased by around $14 \%$. In ED processes, it was also observed this phenomenon. In the same sense of UF, this phenomenon increases the resistance, reducing the efficiency of ED system, and, for this reason, removal rate of the ions from the studied system was modified. These results point to the possible combination of UF and ED to treat the whey and the using of resulting solutions as inputs in new applications, such as lactose.

\section{Acknowledgements}

This work was developed with institutional infrastructure financed by FAPERGS and CNPq (310253/2016-0, CNPq 465571/2014-0).

\section{References}

[1] Małgorzata, W., Monika, J., Maria, S. S., Lidia, Z., Fabian, D., Pawel, B., Tomasz, J., Beata, S., ACID whey concentrated by ultrafiltration a tool for modeling bread properties, LWT - Food Science and Technology 61 (1) (2015)

$172-176$.

https://doi.org/10.1016/j.1wt.2014.11.019.

[2] Geoffrey, W. S., Whey and whey proteins-From 'gutter-to-gold', International Dairy Journal 18 (7) (2008)

695-704.

https://doi.org/10.1016/j.idairyj.2008.03.008.

[3] Das, M., Raychaudhuri, A., Ghosh, S. K., Supply Chain of Bioethanol Production from Whey: A Review, Procedia Environmental Sciences 35 (2016) 833-846. https://doi.org/10.1016/j.proenv.2016.07.100. 
[4] Salvatore, E., Pes, M., Falchi, G., Pagnozzi, D., Furesi, S., Fiori, M., Roggio, T., Addis, M. F., Pirisi, A., Effect of whey concentration on protein recovery in fresh ovine ricotta cheese, Journal of Dairy Science 97 (8) (2014) 4686-4694. https://doi.org/10.3168/jds.20137762 .

[5] Díaz-Vergara, L., Pereyra, C. M., Montenegro, M., Pena, G. A., Aminahuel, C. A., Cavaglieri, L. R., Encapsulated whey-native yeast Kluyveromyces marxianus as a feed additive for animal production, Food Additives \& Contaminants: Part A 34 (5) (2017) 750-759.

https://doi.org/10.1080/19440049.2017.1290830.

[6] Agüero, R., Bringas, E., San Román, M. F., Ortiz, I., Ibáñez, R., Membrane Processes for Whey Proteins Separation and Purification. A Review, Current Organic

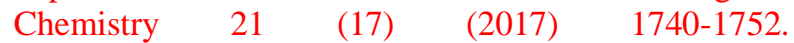
https://doi.org/10.2174/1385272820666160927122523.

[7] Saffari, M., Langrish, T., Effect of lactic acid inprocess crystallization of lactose/protein powders during spray drying, Journal of Food Engineering 137 (2014) 88-94. https://doi.org/10.1016/j.jfoodeng.2014.04.002.

[8] Chen, G. Q., Eschbach, F. I. I., Weeks, M., Gras, S. L., Kentish, S. E., Removal of Lactic Acid from Acid Whey Using Electrodialysis, Separation and Purification Technology 158 (2016) 230-237. https://doi.org/10.1016/j.seppur.2015.12.016.

[9] Kumar, P., Sharma, N., Ranjan, R., Kumar, S., Bhat, S. F., Jeong, D. K., Perspective of Membrane Technology in Dairy Industry: A Review, AsianAustralasian Journal of Animal Sciences 26 (9) (2013) 1347-1358. https://doi.org/10.5713/ajas.2013.13082.

[10] Iltchenco, S., Preci, D., Bonifacino, C., Fraguas, E. F., Steffens, C., Panizzolo, L. A., Colet, R., Fernandes, I. A., Abirached, C., Valduga, E., Steffens, J., Whey protein concentration by ultrafiltration and study of functional properties, Ciência Rural 48 (5) (2018) https://doi.org/10.1590/0103-8478cr20170807.

[11] Dlask, O., Václavíkova, N., Electrodialysis with ultrafiltration membranes for peptide separation, Chemical Papers 72 (2) (2017) 261-271. https://doi.org/10.1007/s11696-017-0293-6.

[12] Ndiaye, N., Pouliot, Y., Saucier, L., Beaulieu, L., Bazinet, L., Electroseparation of bovine lactoferrin from model and whey solutions, Separation and Purification $\begin{array}{lllll}\text { Technology } & 74 & \text { (1) 93-99. }\end{array}$ https://doi.org/10.1016/j.seppur.2010.05.011.

[13] Baldasso, C., Barros, T. C., Tessaro, I. C., Concentration and purification of whey proteins by ultrafiltration, Desalination 278 (1-3) (2011) 381-386. https://doi.org/10.1016/j.desal.2011.05.055.

[14] Tanaka, Y., Current density distribution and limiting current density in ion-exchange membrane electrodialysis, Journal of Membrane Science 173 (2) (2000) 179-190. https://doi.org/10.1016/S03767388(00)00368-9.

[15] Macedo, A., Duarte, E., Pinho, M., The role of concentration polarization in ultrafiltration of ovine cheese whey, Journal of Membrane Science 381 (1-2) (2011) 34-40. https://doi.org/10.1016/j.memsci.2011.07.012.

[16] Konrad, G., Kleinschmidt, T., Faber, W., Ultrafiltration flux of acid whey obtained by lactic acid fermentation, International Dairy Journal 22 (1) (2012) 73-77. https://doi.org/10.1016/j.idairyj.2011.08.005.

[17] Brião, V. B., Tavares, C. R. G., Favaretto, D. P. C., Hemkemeier, M., Ultrafiltration of model and Industrial dairy wastewater, CIATEC Journal 7 (1) (2015) 1-12. https://doi.org/10.5335/ciatec.v7i1.3367.

[18] Mendes, P. R. A., Faria, L. F. F., Avaliação do uso de processos de separação por membranas em efluentes de laticínios pré-tratados por coagulação/floculação in Anais do XX Congresso Brasileiro de Engenharia Química, Bucher Chemical Engineering Proceedings 1 (2) (2015) 15084-15091. https://doi.org/10.5151/chemeng-cobeq2014-063024668-181190.

[19] Narong, P., James, A. E., Efficiency of ultrafiltration in the separation of whey suspensions using a tubular zirconia membrane, Desalination 219 (13) (2008) 348-357. https://doi.org/10.1016/j.desal.2007.04.057.

[20] Pérez, A., Andrés, L. J., Álvarez, A., Coca, J., J., Hill, C. G., Electrodialysis of whey permeates and retentates obtained by ultrafiltration, Journal of Food Process Engineering 17 (2) (1994) 177-190. https://doi.org/10.1111/j.1745-4530.1994.tb00334.x.

[21] Baldasso, C., Lazzari, L. K., Scopel, B. S., Marczak, L. D. F., Tessaro, I. C., Whey fractionation through the membrane separation process, Separation Science and Technology 51 (11) (2016) 1862-1871. https://doi.org/10.1080/01496395.2016.1188115. 